International Journal of Social Science And Human Research

ISSN(print): 2644-0679, ISSN(online): 2644-0695

Volume 04 Issue 11 November 2021

DOI: 10.47191/ijsshr/v4-i11-32, Impact factor-5.586

Page No: 3297-3304

\title{
The Impact of the COVID-19 Crisis on The Role of Mothers Towards Their Disabilities Children
}

\author{
Mohammad Ahmed Hammad \\ Special Education department, Faculty of Education, Najran University, Saudi Arabia,
}

\begin{abstract}
The Coronavirus Disease 2019 (COVID-19) crisis has affected Saudi women's daily lifestyle, contributing significantly to increasing pressure on women to have multiple roles both at home and at work. The study therefore aimed to identify the role of women towards their children with disabilities during the COVID-19 epidemic crisis by identifying their roles towards their children with disabilities in the educational, psychological and social aspect. The study used the quantitative approach (social survey). The sample of the study consisted of (336) Saudi mothers of children with disabilities in the southern region of Saudi Arabia with an average age of (35.8) years. A questionnaire was built to identify the role of Saudi women towards their disabled children during the crisis and was developed by the researcher. The results indicated that the role of Saudi women towards their disabled children during the COVID-19 epidemic crisis was of a high level in all areas of practice for the tool. The analysis of the data to answer the main question in the study also revealed the importance of the educational, psychological and social role of Saudi women towards their children with disabilities during the COVID-19 epidemic crisis within the family. In light of these findings, the study recommended the importance of urging responsible people to provide a range of rescue and stimulus packages that also include social protection measures, seeking to empower Saudi women in all sectors of society, and providing them with all means of support to help them achieve their role in society in general.
\end{abstract}

KEYWORDS: COVID-19, Crisis, Mothers, disabled, Saudi Arabia

\section{INTRODUCTION:}

At a time when people with disabilities in normal times are marginalized and uninterested, especially in Arab countries, the Corona crisis that is ravaging the world has cast great fears on this large group, all over the world. The difficult challenges and circumstances created by this crisis have put considerable pressure on the family, children, particularly children with disabilities, thereby disrupting this natural balance in the lives of families.

Although Saudi Arabia has gone through many crises resulting from the spread of such viruses, the 2019 COV outbreak is one of the most severe in Saudi Arabia. The virus began to appear from Wuhan City, Hubei Province, China, and then spread very quickly around the world, and as a result of this highly contagious virus, with no known therapeutic and preventive strategies, the World Health Organization (WHO) was called upon to declare it a global pandemic (Barry et al., 2020). Thus, the countries of the world have been quick to take many precautionary and extraordinary measures to address this epidemic, and to work to reduce its spread within countries (Wilder-Smith \& Freedman, 2020). Saudi Arabia is one of the first countries to seek several early precautionary measures to prevent the spread of the virus among members of the community. On February 27, 2020, entry for Umrah purposes was suspended and the Prophet's Mosque was visited from outside the Kingdom (Gautret et al., 2020). On March 9, 2020, all educational systems in Saudi Arabia were temporarily suspended and replaced by distance learning using virtual classes. This was followed by a nationwide curfew under which only adults were allowed to leave the house, at specified times and in necessary cases (Argaam, 2020). Despite these effective and rapid precautionary and extraordinary decisions, these decisions have contributed to significantly reducing the increase in infections and alleviating the spread of the epidemic within the Kingdom, according to recent Ministry of Health statistics compared to many countries around the world (Health, 2020). However, these measures have had an impact on changing the daily lifestyle within the family not only at the level of Saudi Arabia but also globally, and this is one of the repercussions of crises experienced by any society such as covid-19, as has been pointed out by many studies such as (Cao et al., 2020; Meo, 2020; Pan, 2020; Pietrobelli et al., 2020).

Although this crisis has had a significant impact on family members, it has had a greater impact on persons with disabilities. The presence of a disabled child throughout the day and for weeks at home has led to a change in some routines that have now been an 


\section{The Impact of the COVID-19 Crisis on The Role of Mothers Towards Their Disabilities Children}

integral part of his life (Alkohaiz, 2018). In addition to the cessation of previous activities and practices he is accustomed to, which has made it difficult to control abnormal behaviors, such as crying, tantrums, faster arousal nervousness, sleep disorders, eating disorders, psychological stress and anxiety, a linguistic behavioral setback for not attending related centers and domestic services (Patel, 2020). These pressures on the disabled child and the family have also been compounded by the lack of formal support from schools, temporary services and health-care professionals, as well as the lack of informal support from family members and friends (Toseeb et al., 2020). Given the cultural orientation within Saudi Arabia, women in this country are responsible for caring for the home and all family members living in the home (Sijeeni, 2016). Therefore, the responsibilities of the mother in Saudi Arabia may become very large if the family has a disabled child and if the mother works outside the home (Alkohaiz, 2018). For a working mother, the pressure levels may increase when closure forces her to work from home in the presence of a disabled child in the family, who needs frequent care and assistance in carrying out his or her daily activities (Crehan et al., 2019). Phumzile MlamboNgcuka, Under-Secretary-General of the United Nations and Executive Director of UN Women, explained that the role of women during the COVID-19 crisis is very important, as women have a greater resilience than men. Therefore, women should be given the opportunity to participate in the development of plans and solutions from relevant institutions that seek to avoid the social, psychological and educational effects of this crisis on families within society (Zhang, 2020).

The United Nations (2020) asserts that since the care of children with disabilities within educational, social and health institutions was not available to many families during the closure period, the provision of care for disabled children was more on the mother's shoulders, limiting their ability to work (Unicef et al., 2020). These care work will often be carried out by women more than men, partly because of the persistence of traditional gender roles and partly because of the structure of women's economic participation, which is likely to be part-time, flexible and less paid (Alkohaiz, 2018). Moreira da Silva (2019) Also noted that women worldwide are responsible for $75 \%$ of domestic work within the family. According to the International Labour Organization (ILO), the average work of women worldwide is 4 hours and 25 minutes of domestic work compared to one hour and 23 minutes for men (Pozzan \& Cattaneo, 2020). Despite these many pressures on women, there are many studies that have confirmed their ability to manage any crisis experienced by the family, and this was confirmed by the study (Power, 2020), which indicated that women are exposed to crises significantly, but they have the competencies that make them more resilient in times of crisis. Emerging research also suggests that the COVID-19 crisis and beyond will have many negative effects on women and families for years without proactive interventions by many governments. Many families need to raise and educate their children, whether ordinary or disabled, without institutional support, which is a major pressure on mothers at home (Adisa et al., 2021; Power, 2020).

We argue that the closure caused by the COVID-19 epidemic has demonstrated women's important role towards their disabled children during the COVID-19 crisis. For example, Jessen and Waights (2020) reported that working mothers combine childcare, home education and paid work during this period by working long hours in the evening. Similarly, Andersen et al. (2020) showed that the epidemic has prompted women to devote more time to childcare and home schooling responsibilities, with men still relatively less affected. Recent research in the United States has shown that parents of children under the age of 18 are experiencing more stress due to the COVID-19 virus outbreak and response. Nearly $32 \%$ of fathers reported that their mental health was worse due to infection compared to $57 \%$ of mothers, suggesting that mothers may bear a disproportionately large part of the burden (Hamel \& Salganicoff, 2020). The author argues that the COVID-19 crisis has had a clear impact on the importance of women's role towards their disabled children, joining this growing body of research in an effort to clarify the importance of the role Saudi women play towards their disabled children during the COVID-19 crisis. Accordingly, the problem of study can be formulated in the following main question: What is the role of Saudi women towards their disabled children during the COVID-19 epidemic crisis?

\section{METHOD}

\section{Population}

The sample of 336 mothers with one or more children with disabilities, living in southern Saudi Arabia. The sample age ranged from (23-45 years) $(\mathrm{M}=35.8$ years, $\mathrm{SD}=2.46)$. The sample was diverse from mothers of children with disabilities and the ratio was distributed as follows: $35 \%$ of mothers have children with learning disabilities, $12 \%$ of mothers have children with autism; $15 \%$ have children with physical disabilities. $10.5 \%$ have children with hearing impairment. $8.5 \%$ have children with visual impairment, $10 \%$ have children with ADHD; $4 \%$ have children with linguistic delay, $5 \%$ have children with mental disabilities.

\section{Procedures}

It was the quantitative approach (social survey). Appropriate to the nature of this study, a ct study was conducted after the end of the closing period within Saudi Arabia in February to March 2021. we received the approval of our study from the University of Najran. A link to an online questionnaire was distributed on the social media sites (Twitter, Facebook and WhatsApp) on different groups of mothers in the south of the Kingdom (Female students, faculty, education and health workers, Saudi associations for children with disabilities). Using the snowball sampling technique. The criteria for selecting the sample were as follows: approval to participate in the study, current residence in southern Saudi Arabia and mother of a disabled child. Respondents voluntarily filled 


\section{The Impact of the COVID-19 Crisis on The Role of Mothers Towards Their Disabilities Children}

out questionnaires without any pressure, and while ensuring the confidentiality of the information, more than 412 respondents participated in our survey, 76 of whom were excluded either because they did not meet the sample selection criteria, or because of incomplete responses. Therefore, a total of 336 respondents were included in this study.

\section{Questionnaire}

A questionnaire was used to collect data. It was built by the researcher after reviewing relevant literature such as a study (Andersen et al., 2020; Cui et al., 2020; Jessen \& Waights, 2020; Power, 2020; Sutherland, 2010). The questionnaire contains two parts; the first part is designed to collect basic data such as gender, age, educational level, residence and profession. Part 2: Consists of three dimensions; the first dimension; the educational role of mothers towards their children with disabilities during the COVID-19 crisis, It consists of 7 paragraphs. The second dimension includes the psychological role and contains 6 paragraphs. The third dimension includes the social role and contains 6 paragraphs. The 5-point Lykert scale was used (I strongly agree - I agree - neutral - I do not agree - I strongly disagree), grades were distributed from 5 to $1 ; 1$ for "I strongly disagree" 5 for "I strongly agree." The resolution was tested in terms of face, content and building authority by a jury of 5 experts in the field of special education, social and mental health. Instrument reliability was done using Cronbach's Alpha coefficient test. It indicated high reliability $(0.85,0.88,0.89)$; The overall score for the questionnaire $(\mathrm{r}=0.90)$.

\section{Data analysis:}

The data was analyzed after the data collection was completed, and SPSS Statistics V21 was used to analyze the data. Descriptive statistics were used as number and repeaters, percentage, averages and standard deviation.

\section{RESULTS}

To answer the study's question, "What is the role of Saudi women towards their disabled children during the COVID-19 epidemic crisis?" the standard deviations and percentages of participants' responses to the paragraphs were extracted in the first dimension of the questionnaire. Table 1 presents results.

Table 1: Means, Standard Deviations, Percentage and ranking on the Dimensions of questionnaire

\begin{tabular}{|l|l|l|l|l|l|}
\hline $\begin{array}{l}\text { Saudi women's role towards their disabled } \\
\text { children during the COVID-19 crisis } \\
\text { Sub-Dimensions }\end{array}$ & $\mathrm{M}$ & SD & Proportion & Rank \\
\hline 1 & Educational role & 29.02 & 4.37 & $83.42 \%$ & 1 \\
\hline 2 & psychological role & 24.12 & 4.18 & $80.04 \%$ & 3 \\
\hline 3 & Social role & 24.77 & 4.18 & $82.85 \%$ & 2 \\
\hline Total & 77.91 & 12.86 & $88.53 \%$ & \\
\hline
\end{tabular}

The results in Table 1 reveal the average high score of all dimensions in the questionnaire. Participants showed a high degree of agreement on the importance of women's role towards their disabled children during the COVID-19 crisis. The agreement rate of all dimensions (88.53\%), which shows the importance of the role of Saudi women towards their disabled children during the COVID-19 epidemic crisis. The most important role was the educational role, with the ratio of agreement between participants $(83.42 \%)$, while the lowest indicator was the psychological role at $80.04 \%)$.

The distribution of participants' responses to items in the three dimensions of the questionnaire is displayed in tables 2, 3 and 4 . Table 2 shows. Distribution of participants' responses to the first dimension, which is the educational role.

Table 2. Shows the distribution of participants' responses to the first dimension namely Educational role.

\begin{tabular}{|l|l|l|l|l|l|}
\hline \multicolumn{2}{|l|}{ Items (Educational role) } & $\mathrm{M}$ & $\mathrm{SD}$ & $\%$ & Rank \\
\hline 1 & $\begin{array}{l}\text { I tried to explain to my disabled son what } \\
\text { COVID-19 is, why we stay at home, and not go } \\
\text { to school or rehabilitation centers. }\end{array}$ & 4.13 & 1.05 & 82.6 & 5 \\
\hline 2 & $\begin{array}{l}\text { I spoke to my disabled son about the COVID- } \\
19 \text { epidemic, the reasons we stayed at home, } \\
\text { and not going to school or rehabilitation } \\
\text { centers. }\end{array}$ & 4.25 & 1.32 & 85 & 2 \\
\hline 3 & $\begin{array}{l}\text { I took responsibility for reviewing lessons for } \\
\text { my children during the closure period }\end{array}$ & 4.45 & 1.20 & 89 & 1 \\
\hline
\end{tabular}


The Impact of the COVID-19 Crisis on The Role of Mothers Towards Their Disabilities Children

\begin{tabular}{|l|l|l|l|l|l|}
\hline 4 & $\begin{array}{l}\text { Contact relevant institutions to provide some } \\
\text { online treatment or counselling sessions to my } \\
\text { disabled son. }\end{array}$ & 4.22 & 1.03 & 84.4 & 3 \\
\hline 5 & $\begin{array}{l}\text { I earned my disabled son a lot of good behavior } \\
\text { through semi-organized play activities. }\end{array}$ & 4.02 & 1.12 & 80.4 & 7 \\
\hline 6 & $\begin{array}{l}\text { I have been communicating weekly with } \\
\text { caregivers to consult them and benefit from } \\
\text { their experience in dealing with my disabled } \\
\text { son. }\end{array}$ & 3.98 & 0.94 & 79.6 & 83 \\
\hline 7 & $\begin{array}{l}\text { I have always maintained contact with the } \\
\text { school or related centers. }\end{array}$ & 4.15 & 0.89 & 4 \\
\hline Total & 29.02 & 4.37 & 83.42 & \\
\hline
\end{tabular}

Findings in table 2 shows that the relative weight for items in the first dimension namely Educational role was ranging from (89 \%) for the phrase that " I took responsibility for reviewing lessons for my children during the closure period ". to (80.04\%) for the phrase that " I earned my disabled son a lot of good behavior through semi-organized play activities". Whilst the relative weight for the whole dimension was $(83.42 \%)$ indicating that importance of the educational role of Saudi women towards their children with disabilities during the COVID-19 crisis.

Table 3. Presents the distribution of participants' responses to items in the second dimension of the first field of the questionnaire namely "The psychological role".

\begin{tabular}{|c|c|c|c|c|c|}
\hline \multicolumn{2}{|c|}{ Items (The psychological role) } & \multirow{2}{*}{$\begin{array}{l}\mathrm{M} \\
4.22\end{array}$} & \multirow{2}{*}{$\begin{array}{l}\text { SD } \\
0.98\end{array}$} & \multirow{2}{*}{$\%$} & \multirow[b]{2}{*}{2} \\
\hline 1 & $\begin{array}{l}\text { She refused to leave the house after covid-19 spread } \\
\text { out of fear of infecting my disabled son. }\end{array}$ & & & & \\
\hline 2 & $\begin{array}{l}\text { Although I felt insomnia because I feared for my } \\
\text { disabled son to have COVID-19, I tried to look } \\
\text { strong in front of him. }\end{array}$ & 4.12 & 1.04 & 82.4 & 3 \\
\hline 3 & $\begin{array}{l}\text { I often look strict or harsh in my feelings for others } \\
\text { so that no one visits us at my house for fear of covid- } \\
19 \text { infection. }\end{array}$ & 3.89 & 1.21 & 77.8 & 4 \\
\hline 4 & $\begin{array}{l}\text { I am deeply afraid for my health and that of my } \\
\text { disabled son from the spread of this epidemic. }\end{array}$ & 4.35 & 1.02 & 87 & 1 \\
\hline 5 & $\begin{array}{l}\text { Although I am depressed by the many daily } \\
\text { pressures on me, I have tried to look happy and } \\
\text { cooperative with my family. }\end{array}$ & 3.82 & 0.88 & 76.4 & 5 \\
\hline 6 & $\begin{array}{l}\text { Despite the news that there were many deaths due to } \\
\text { COVID-19 that made me upset, I tried to avoid my } \\
\text { disabled children hearing this news as much as } \\
\text { possible. }\end{array}$ & 3.72 & 1.12 & 74.4 & 6 \\
\hline \multicolumn{2}{|c|}{ Total } & 24.12 & 4.18 & 80.04 & \\
\hline
\end{tabular}

Table 3 reveals that the relative weight of all items in the second dimension "The psychological role" ranged between (87\%) for the phrase that "I am deeply afraid for my health and that of my disabled son from the spread of this epidemic". And (74.4\%) for the statement that "Despite the news that there were many deaths due to COVID-19 that made me upset, I tried to avoid my disabled children hearing this news as much as possible". Whereas, the relative weight of the second dimension as a whole was (80.04\%) indicating that importance of the psychological role of Saudi women towards their children with disabilities during the COVID-19 crisis.

Table 4. Presents the distribution of participants' responses to items in the third dimension of the first field of the questionnaire namely "Social role". 
The Impact of the COVID-19 Crisis on The Role of Mothers Towards Their Disabilities Children

\begin{tabular}{|c|c|c|c|c|c|}
\hline \multicolumn{2}{|c|}{ Items (Social role) } & M & SD & $\%$ & \\
\hline 1 & $\begin{array}{l}\text { I took advantage of the closure period to strengthen my relationship with my } \\
\text { disabled son. }\end{array}$ & 4.21 & 1.14 & 84.2 & 3 \\
\hline 2 & I have dealt with increasing the duties of caring for my disabled child positively. & 4.38 & 1.22 & 87.6 & 1 \\
\hline 3 & $\begin{array}{l}\text { Although it is difficult to balance work with taking care of my children with } \\
\text { disabilities, I have tried to make a double effort to get through this crisis.. }\end{array}$ & 4.15 & 1.24 & 83 & 4 \\
\hline 4 & $\begin{array}{l}\text { Although caring for my disabled son has increased my home burden besides my } \\
\text { professional work, I have reduced my relationships to save some time. }\end{array}$ & 3.84 & 0.96 & 76.8 & 6 \\
\hline 5 & $\begin{array}{l}\text { I realized that it is important to give my disabled children a large part of our time } \\
\text { to avoid acquiring negative behaviors. }\end{array}$ & 4.23 & 1.19 & 84.6 & 2 \\
\hline 6 & $\begin{array}{l}\text { Play activities in collaboration with his brothers have been used to give my } \\
\text { children with disabilities a lot of skills and improve social awareness. }\end{array}$ & 3.96 & 1.09 & 79.2 & 5 \\
\hline \multicolumn{2}{|c|}{ Total } & 24.77 & 4.39 & 82.85 & \\
\hline
\end{tabular}

Table 4 indicates that the relative weight of all items in the third dimension "Social role" were between $(87.2 \%)$ for the fact that "I have dealt with increasing the duties of caring for my disabled child positively". In addition (76.8\%) for the statement that "Although caring for my disabled son has increased my home burden besides my professional work, I have reduced my relationships to save some time". Whereas, the relative weight of the Third dimension as a whole was $(82.85 \%)$ indicating that importance of the Social role of Saudi women towards their children with disabilities during the COVID-19 crisis.

\section{DISCUSSION}

The results of our study indicated the effectiveness of women's role towards their disabled children during the COVID-19 pandemic, as demonstrated by their roles in the educational, social and psychological aspects, which the sample responses showed on the dimensions of resolution. The educational role was ranked first in the study sample responses; In light of the COVID-19 epidemic crisis, Saudi women have become more responsible for learning. COVID-19 surprised the whole world, particularly mothers who were surprised by the closure of schools and took responsibility for educating children in isolation conditions, this has confused everyone and has become a source of stress and anxiety for the future of children in general and people with disabilities in particular. This was confirmed by Cahapay (2020), who noted that in addition to hard work outside the home, managing family affairs and caring for children's welfare, many mothers suddenly found themselves on another difficult task: Supervising their children's education at home.

The rehabilitation and education of children with disabilities has focused on the collaborative effort between school and family, which is known as the concept of partnership. As a result of the COVID-19 crisis and isolation procedures, mothers, through remote communication with the school and special centres for persons with disabilities, agreed on educational plans in light of the current crisis, The mother's role in giving a child with disabilities academic and personal skills while at home. The results of the study indicated the effectiveness of the mother in performing her educational role towards her disabled children effectively. Many mothers in the crisis have found an opportunity to adapt and innovate in educating their disabled children in the belief that the quality of the educational process will not be affected by closure. This was confirmed by (Farré et al., 2020; Spinelli et al., 2020) where he noted that with the closure of schools and childcare centres with disabilities during the epidemic, families with disabled children were left with responsibilities to care for their children including in-house education. The results of their study also indicated that the traditional distribution of both sexes to work within the family disproportionately affects men and women; The closure may have forced women to prioritize the responsibilities of caring for their disabled children in line with the cultural ideals of a good mother to promote traditional gender roles at home (Sutherland, 2010).

The dimension of the social role was also in second place at the level of the three dimensions; my average account is high, which also shows the importance of the social role women play towards their children with disabilities during the COVID-19 crisis. Women in Arab culture in general and Saudi Arabia in particular are the first line of defense for the family, and protecting it from the injury of covid-19 members, Since we find that the role of women is great during this crisis and without it we will find that the state's precautionary measures will not come with the desired result (Alkohaiz, 2018; Alshoaibi, 2018; Cui et al., 2020; Di Giorgio et al., 2020). A mother is instrumental in getting her children used to practice healthy behaviors important to protect her family from COVID-19: personal hygiene, hand washing, use of sneezing and cough wipes and then disposing of them and washing hands with soap and water (Chen et al., 2020). The mother also contributes to raising the immunity of her family members by providing appropriate healthy food for family members. In addition, its ability to provide attractions that encourage family members to commit to staying at home during the ban on non-infection. This was confirmed by (Adisa et al., 2021; Khwela-Mdluli \& Beharry-Ramraj, 2020; Staniscuaski et al., 2020) that women's commitments during that COVID-19 crisis doubled and increased. The importance of 


\section{The Impact of the COVID-19 Crisis on The Role of Mothers Towards Their Disabilities Children}

the social role played by the Saudi mother through the unequal distribution of family care work between men and women was also evident. In normal times, women and girls are responsible for caring for the family and the home because of social traditions. And during the COVID-19 crisis they are now likely to bear the increase in care work responsibilities resulting from school closures and increased social responsibilities towards their disabled children and their families. The results are also consistent with many studies such as (Khwela-Mdluli \& Beharry-Ramraj, 2020; Power, 2020; Staniscuaski et al., 2020).

The third dimension of the psychological role of Saudi women towards their disabled children during the COVID-19 crisis also came in the last order at the level of three dimensions. However, it also has a high average account, which also demonstrates the importance of the psychological role women play towards their disabled children during the COVID-19 crisis. This can be explained by the ability of Saudi women to cope with the psychological pressures within the family resulting from the spread of COVID-19 in the light of some factors surrounding the environment of Saudi women living in them. Where cultural and social factors and the culture, customs and traditions that include in them most women grew up in an environment, that is considered to be best suited for women is home and reproduction (Alshoaibi, 2018; Vidyasagar \& Rea, 2004). Thus, in such circumstances, Saudi women have a double responsibility to protect their families, especially their children with disabilities, from the global epidemic, Regardless of her inner sense of fear of the unknown, she wears a mask of power and indifference to reassure those around her, and tries to manage the psychological crises resulting from quarantine with composure. Also, work to create a healthy atmosphere at home and exploit the times of isolation as a valuable and entertaining time for the family. This has been confirmed by studies (Durankuş \& Aksu, 2020; Pozzan \& Cattaneo, 2020) That women in the midst of the covid-19 crisis that the country has gone through and continues to try to suppress their negative feelings and emotions in the hope that the crisis will pass peacefully. Women's concerns in this matter are more than men' and this compounds their psychological troubles, as they face fear not only for their lives but also for the lives of their children, husband and family. This is what Di Giorgio et al., 2020 has pointed out; Spinelli et al., 2020) that mothers often develop "panic and fear" when a disease, microbe, or virus spreads, which is normal, they fear for their young in normal times. . This is clarified by Di Giorgio et al., 2020; Spinelli et al., 2020) that mothers often develop "panic and fear" when a disease, microbe, or virus spreads, which is normal, they fear for their young in normal times. Here, Saudi mothers are increasingly playing a role in spreading awareness and following the right behavioural models in adhering to preventive measures and taking precautions to prevent the spread of negative psychological responses within the family because of this crisis. This is through the emotional stability and psychological rigidity that she shows during this crisis in front of her family. This has been confirmed by the results of some studies such as (Khwela-Mdluli \& Beharry-Ramraj, 2020; Pozzan \& Cattaneo, 2020; Staniscuaski et al., 2020).

Conclusion

The paper reviewed the results of research on the role of Saudi women towards their children with disabilities during the COVID19 pandemic, by measuring the roles of Saudi women during this crisis. The main contribution of this research is that it provides a deeper understanding of the role Saudi mother's play towards their children with disabilities during the COVID-19 epidemic crisis; In particular, this issue is new to the international community, including Saudi society. . Hence, this study attempted to shed light on the importance of the role of Saudi women towards their children with disabilities during the COVID-19 pandemic, and the extent of the educational, social, and psychological role that they play within the family. We find that the role of women in this crisis and their family responsibility have increased and they have fallen on their shoulders under these circumstances, as their tolerance ensures the success of the precautionary measures taken by the state to counter the spread of the deadly virus. Women are the first line of defence for the family and protect them from the infection of a family member, especially her children with disabilities, with COVID-19. This goal will not be achieved without the participation of women, who are responsible for educating their children in partnership with schools or special education centers with the implementation of the distance learning system. In addition, they have academic and social skills and maintain their psychological aspects. It has also sought to maintain healthy aspects. Also, they are able to provide attractions that encourage family members to commit to staying at home during the period imposed for non-movement. It must therefore be aware that the role of women in covid-19 is essential in spreading hope, raising morale and maintaining the psychosocial balance of the family and children, whether ordinary or disabled. We hope that the results of this research will encourage officials to look at this vital issue in greater depth and to provide full support to Saudi women in order to help them achieve their role during this crisis towards their disabled children.

\section{REFERENCES}

1) Adisa, T. A., Aiyenitaju, O., \& Adekoya, O. D. (2021). The work-family balance of British working women during the COVID-19 pandemic. Journal of Work-Applied Management .

2) Alkohaiz, M. A. (2018). Educational, financial, and social needs of families of children with multiple disabilities in Saudi Arabia .

3) Alshoaibi, M. (2018). Identity Negotiation, Saudi Women, and the impact of the 2011 royal decree: An investigation of the cultural, religious, and societal shifts among women in the Saudi Arabian Public Sphere. 


\section{The Impact of the COVID-19 Crisis on The Role of Mothers Towards Their Disabilities Children}

4) Andersen, J. P., Nielsen, M. W., Simone, N. L., Lewiss, R. E., \& Jagsi, R. (2020). Meta-Research: COVID-19 medical papers have fewer women first authors than expected. Elife, 9, e58807 .

5) Argaam. (2020, 5/4/2020). Find out about actions taken by Saudi Arabia to prevent the spread of "Corona" and reduce the effects of which. Argaam. Retrieved 5/4/2020 from

6) Barry, M., Al Amri, M., \& Memish, Z. A. (2020). COVID-19 in the Shadows of MERS-CoV in the Kingdom of Saudi Arabia. Journal of Epidemiology and Global Health, 10(1), 1-3 .

7) Cahapay, M. B. (2020). How Filipino parents home educate their children with autism during COVID-19 period. International Journal of Developmental Disabilities, 1-4 .

8) Cao, W., Fang, Z., Hou, G., Han, M., Xu, X., Dong, J., \& Zheng, J. (2020). The psychological impact of the COVID-19 epidemic on college students in China. Psychiatry Research, 287, 112934-112934

. https://doi.org/10.1016/j.psychres.2020.112934

9) Chen, X., Ran, L., Liu, Q., Hu, Q., Du, X., \& Tan, X. (2020). Hand hygiene, mask-wearing behaviors and its associated factors during the COVID-19 epidemic: A cross-sectional study among primary school students in Wuhan, China. International journal of environmental research and public health, 17(8), 2893.

10) Crehan, C., Kesler „E., Nambiar, B., Dube, Q., Lufesi, N., Giaccone, M., Normand, C., Azad, K., \& Heys, M. (2019). The NeoTree application: developing an integrated mHealth solution to improve quality of newborn care and survival in a district hospital in Malawi. BMJ global health, 4(1), e000860 .

11) Cui, R., Ding, H., \& Zhu, F. (2020). Gender inequality in research productivity during the COVID-19 pandemic. arXiv preprint arXiv:2006.10194

12) Di Giorgio, E., Di Riso, D., Mioni, G., \& Cellini, N. (2020). The interplay between mothers' and children behavioral and psychological factors during COVID-19: an Italian study. European child \& adolescent psychiatry, 1-12 .

13) Durankuş, F., \& Aksu, E. (2020). Effects of the COVID-19 pandemic on anxiety and depressive symptoms in pregnant women: a preliminary study. The Journal of Maternal-Fetal \& Neonatal Medicine, 1-7 .

14) Farré, L., Fawaz, Y., González, L., \& Graves, J. (2020). How the COVID-19 lockdown affected gender inequality in paid and unpaid work in Spain

15) Gautret, P., Al-Tawfiq, J. A \& ,.Hoang, V. T. (2020). COVID 19: Will the 2020 Hajj pilgrimage and Tokyo Olympic Games be cancelled?

16) Hamel, L., \& Salganicoff, A. (2020). Is there a widening gender gap in coronavirus stress. Retrieved from .

17) Health, M. o. (2020). Follow-up Committee updates Corona held its meeting No. 46, and notes the efforts of all harmony related sectors. Ministry of Health

18) Retrieved 2020/04/05 from https://www.moh.gov.sa/Ministry/MediaCenter/News/Pages/News-2020-04-05-008.aspx

19) Jessen, J., \& Waights, S. (2020). Effects of COVID-19 day care centre closures on parental time use: Evidence from Germany. VoxEU column .

20) Khwela-Mdluli, N., \& Beharry-Ramraj, A. (2020). THE EFFECT OF COVID-19 ON WORKING WOMEN IN SOUTH AFRICA. Gender \& Behaviour, $18(4$

21) Meo, S. A. (2020.(COVID-19 pandemic: Saudi Arabia's role at national and international levels. Journal of Diabetes Science and Technology, 14(4), 758-759.

22) ]Record \#6 is using a reference type undefined in this output style[.

23) Pan, H. (2020). A glimpse of university students' family life amidst the COVID-19 virus. Journal of Loss and Trauma, 25(6-7), 594-597.

24) Patel, K. (2020). Mental health implications of COVID-19 on children with disabilities. Asian journal of psychiatry, 54, 102273 .

25) Pietrobelli, A., Pecoraro, L., Ferruzzi, A., Heo, M., Faith, M., Zoller, T., Antoniazzi, F., Piacentini, G., Fearnbach, S. N., \& Heymsfield, S. B. (2020). Effects of COVID-19 Lockdown on Lifestyle Behaviors in Children with Obesity Living in Verona, Italy: A Longitudinal Study. Obesity .

26) Power, K. (2020). The COVID-19 pandemic has increased the care burden of women and families. Sustainability: Science, Practice and Policy, 16(1), 67-73.

27) Pozzan, E., \& Cattaneo, U. (2020). Women health workers: Working relentlessly in hospitals and at home .Geneva: International Labour Organisation, Available online:

https://www. ilo. org/global/about-the-ilo/newsroom/news/WCMS_741060/lang--en/index. htm (accessed on 16 October $2020 .($

28) Sijeeni, A. S. M. (2016). Understanding the experiences of mothers caring for children with down syndrome in Saudi Arabia Queensland University of Technology .[ 


\section{The Impact of the COVID-19 Crisis on The Role of Mothers Towards Their Disabilities Children}

29) Spinelli, M., Lionetti, F., Pastore, M., \& Fasolo, M. (2020). Parents' stress and children's psychological problems in families facing the COVID-19 outbreak in Italy .Frontiers in Psychology, 11, 1713.

30) Staniscuaski, F., Reichert, F., Werneck, F. P., de Oliveira, L., Mello-Carpes, P. B., Soletti, R. C., Almeida, C. I., Zandona, E., Ricachenevsky, F. K., \& Neumann, A. (2020). Impact of COVID-19 on academic mothers. Science, 368(6492), 724724 .

31) Sutherland, J. A. (2010). Mothering, guilt and shame. Sociology Compass, 4(5), 310-321 .

32) Toseeb, U., Asbury, K., Code, A., Fox, L., \& Deniz, E. (2020). Supporting families with children with special educational needs and disabilities during COVID-19.

33) Unicef, Plan-International, \& Women, U. (2020). A new era for girls: taking stock of 25 years of progress. Unicef .

34) Vidyasagar, G., \& Rea, D. M. (2004). Saudi women doctors: gender and careers within Wahhabic Islam and a 'westernised'work culture. Women's studies international forum ,

35) Wilder-Smith, A., \& Freedman, D. O. (2020). Isolation, quarantine, social distancing and community containment: pivotal role for old-style public health measures in the novel coronavirus (2019-nCoV) outbreak. Journal of travel medicine .

36) Zhang, H. (2020). The influence of the ongoing COVID-19 pandemic on family violence in China. Journal of family violence, $1-11$. 